\title{
大転子の骨切り・再接着の一工夫
}

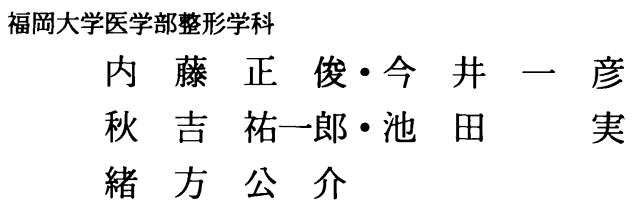

\section{A New Dihedral Osteotomy of the Greater Trochanter}

by

\author{
Masatoshi Naito, Kazuhiko Imai, Yuichiro Akiyoshi, \\ Minoru Ikeda and Kosuke Ogata
}

Department of Orthopaedic Surgery, Fukuoka University School of Medicene

\begin{abstract}
A New method of performing a dihedral trochanteric osteotomy was designed to overcome osteotomy nounion and trochanteric bursitis secondary to wire breakage. The osteotomy was performed in two-steps with a side-cutting power saw and was started distal to the abductor tubercle. The first step of the osteotomy was done in an oblique direction similar to the usual fashion and stopped en route from the abductor tubercle to the femoral neck. Next, the blade of a side-cutting power saw was inserted between the capsule of the hip joint and the tendons of the gluteal muscles. The second step of the osteotomy was performed in a vertical direction from the tip of the greater trochanter until it reached the site of the first osteotomy. A v-shaped osteotomy of the greater trochanter was compleated with the apex of the osteotomy medical and the trochanteric fragment was retracted proximally. After operative procedures to the acetabulum were done, the trochanteric fragment was reduced into the original position and fixed with a single screw. The results of the first 24 hips in 23 patients were prospectively studied. At operation, reduction and fixation of the trochanter to its bed were easily performed because of the dihedral osteotomy. This method was found neither to prolong the operation time nor to increase blood loss. In all hips, osseous union of the greater trochanter was obtained and there was no trochanteric bursitis. The advantages of this type of osteotomy are obvious. Not only is rotation resisted but anatomical replacement of the trochanter is made easier, and the surface area of the osteotomy is increased.
\end{abstract}

Key words : Greater Trochanter (大転子), Non-union (偽関節), New Osteotomy（新しい骨切り）

\section{はじめに}

大転子を骨切りし，中・小殿筋ととも反転すること は, 股関節周囲の広範な展開に有用な方法である。し かし，この方法は，術後大転子部の偽関節や鋼線の破 損による滑液包炎を起こすことがある．この合併症を 減らすために, 鋼線が不要で, しかも, 骨癒合に有利と なるような大転子の骨切りを行っているので報告する.

\section{対象及び方法}

対象は，本方法を開始した 1993 年 1 月からの 23 症 例, 24 股関節症例である. 内訳は, 寛骨臼移動術 ${ }^{3)} 19$ 症例, 20 股関節之骨盤骨折に対する観血的整復術 ${ }^{1}$ の 4 症例と 4 股関節である. 症例の手術時年齢は 18 歳から 54 歳まで, 平均 41.4 歳であった。 大転子の骨 切りは二平面で行う様にした。 ボーンンーにて外側広 
筋の起始部よりやや近位の大転子の末梢から中枢に向 け大腿骨頸軸とほぼ平行に第一の斜めの骨切りを加え る. 第二の骨切りを大転子の先端で中・小殿筋の内側 から末梢に向け大腿骨幹部之ほぼ平行な垂直の骨切り を第一の骨切り部まで行い，外開きのV字型となった 大転子を切離する，再接着には螺子を一本用いている.

\section{症 例 供 覧}

今回のシリーズで唯一の両側例である. 44 歳の農 家の主婦で，両側股関節亜脱臼障害による進行期变形 性股関節症である，左側では荷重部関節裂隙の消失， 臼蓋部の骨棘形成や骨裳包，骨頭内側にも骨棘形成が 認めら，股関節症の末期に近ずいている（図 1 ）。患 者の年齢などを考慮し，寛骨臼移動術を SALVAGE OSTEOTOMY として行った. 両側と屯術後， CE 角 が約 40 度, 骨頭の内側化が約 $1 \mathrm{~cm}$ 得られ，左側では 関節裂隙の開大が認められている(図 2 )。左側が術 後 2 年, 右側が 8 力月の現在, 疼痛が著明に改善し,

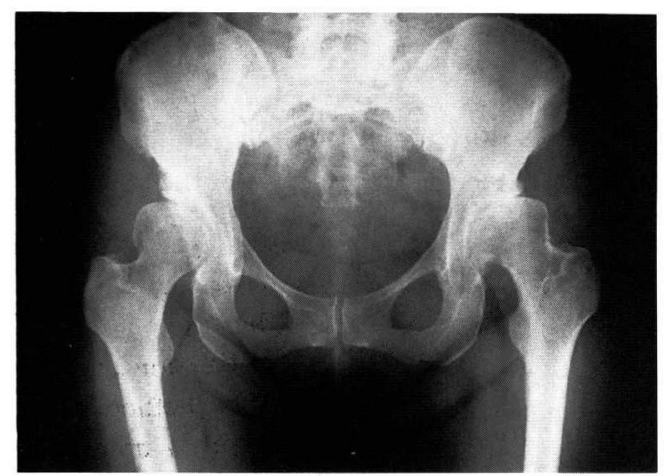

図 1 対象疾患44 歳, 女性の術前両股正面レ線像.

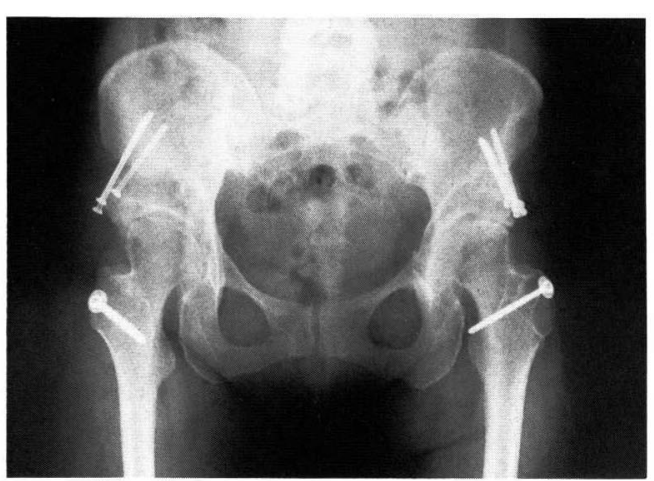

図 244 歳, 女性の術後両股正面レ線像.
農業を手伝っている，大転子部には愁訴を訴えていな い

$$
\text { 結 果 }
$$

現在まで大転子部の偽関節や滑液包炎は皆無である. また，大転子部の骨折や螺子の破損などの合併症も認 められていない.

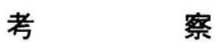

我々が渉猟し得た範囲では, 二平面で行う大転子の 骨切り法は Weber ら ${ }^{4)}$, 及び, Wroblewski ら ${ }^{5)} に$ よって報告されているのみである. 何れの方法も大転 子を矢状面からみて逆 $\mathrm{V}$ 字型に切る方法であるが, 中 枢骨片が小さく，技術的に容易とは思えない，また， 鋼線の破損による滑液包炎可能性屯残存している. 我々 の考案した方法では，中枢骨片が大きく，このため骨 切り面がより増加している. また, 中殿筋の作動べク トルの水平成分は, 垂直の骨切り面を圧迫する作用が あると考えられる。これらのことは，骨瘉合や骨切り 部の固定に有利に㗢くと思われる. 骨切り部の機械的 要因とともに血行動態も骨癒合に関連があると考えら れる. 大転子部は，閉鎖した成長帯部付近を境として 主に骨外からの血管により栄養されている ${ }^{2)}$.このこ とは，あまり浅く大転子の骨切りを行うことは大転子 部の母床の血行に不利であると示唆している. このた め，我々の斜めの骨切りは，閉鎖した成長帯部付近で 行ってる.

結語

大転子部の骨切りを二平面で行う新しい方法を考察 した．現在まで 24 股関節の展開に用い，大転子部の 偽関節や滑液包炎は皆無である。

\section{参 考 文 献}

1) Mears, D.C., Rubash, H.E. : Triradiate Extensile Approach, CAMPBELL'S OPERATIVE ORTHOPAEDICS (Eighth Edition), pp79-83, Crenshaw, A.H., St. Louis, Mosby, 1992.

2) Naito, M., Ogata, K., Emoto, G. : Blood Supply to the Greater Trochanter. Clin. Orthop. in press.

3）西尾篤人：先天性股関節脱臼に対する脾臼移動による 観血的製復術. 日整会誌， $3: 482,1956$.

4) Weber. B.G., Stuhmer, G. : Improvements in Total Hip Prosthesis Implantation Technique. A CementProof Seal for the Lower Medullary Cavity and a 
Dihedral Self-Stabilizing Trochanteric Osteotomy. Arch. Orthop. Traumat. Surg., 93 : 185-189, 1979.

5) Wroblewski, B.M. : Reattachment of the Greater
Trochanter after Hip Replacement. J. Bone Joint Surg., 67B : 736-740, 1985.

(N) 